\title{
La divinidad celeste/solar en el panteón céltico peninsular
}

\author{
The solar divinity among the celtic gods \\ of the Iberian Peninsula
}

\author{
RubÉn AbAd LARA* \\ Plan Director de Numancia
}

\begin{abstract}
RESUMEN
ABSTRACT

En la Hispania prerromana existió una divinidad suprema con carácter celeste y solar de tipo similar a la que se rindió culto en el resto de la Europa indoeuropea. El análisis de algunas piezas del arte celtibérico, nos revela que esa divinidad principal era representada bajo la forma de un jinete a caballo con lanza. La iconografía muestra que ese dios, uno de

cuyos nombres pudo ser Lugus, tomó parte de numerosos mitos que le relacionaban con la guerra, la fertilidad y el mundo funerario.

In preroman Spain there was a supreme divinity with solar and heavenly roles, very similar to the divinities worshiped in the rest of the indoeuropean Europe. The analysis of some celtiberian pieces of art, revealed to us that this principal divinity was depicted in the form of a horseman on his horse and holding a spear. The iconography shows that this God, one of his names could be Lugus, took part in many myths which linked him to war, fertility and the funerary world.

\section{PALABRAS CLAVE}

Religión celtibérica; símbolos solares; divinidad celeste; jinete divino; mitos; cacería divina.

\section{KEYWORDS}

Celtiberian Religión; sun symbols; God of Heavens; divine horseman; myths; divine hunting.
\end{abstract}

\section{INTRODUCCIÓN}

Cuando hablamos del panteón céltico peninsular, hacemos referencia al sistema articulado de divinidades y creencias que poseyeron los pueblos prerromanos del área indoeuropea y del que lo que sabemos, suele ser cuanto menos equivalente a lo que no sabemos.

* Plan Director de Numancia. Correo electrónico: r.abad_lara@ @otmail.es 
Se conocen más de tres centenares de divinidades en la Península Ibérica entre nombres y epítetos, la mayoría de ellos procedentes de la epigrafía. Este enorme volumen de divinidades, unido a la escasez de información que nos proporcionan las fuentes escritas, ha venido haciendo imposible cualquier intento de establecer un sistema cosmogónico o de ordenación del panteón, hasta el punto de que ni siquiera se ha tenido seguridad de que algo así hubiese existido'. Esa falta de información ha devenido en una gran confusión a la hora de reinterpretar la interpretatio romana, algo particularmente visible en la epigrafía, donde los epítetos indígenas que acompañan a los dioses romanos, en lugar de ayudar a identificar a las divinidades, suelen a menudo conducir a mayores confusiones y problemas, algo extensible en general al mundo celta Europeo ${ }^{2}$. En lo que respecta a la celtiberia, la epigrafía nos muestra unos treinta teónimos, pudiendo suponer que no todos se refieren a divinidades distintas, sino que diferentes nombres pueden hacer referencia a una misma divinidad ${ }^{3}$. Cada etnia o región podía tener una o varias divinidades propias o bien una forma propia de invocar a una única divinidad de carácter más globalizante ${ }^{4}$, siendo esto último algo probablemente muy habitual y origen de la mayor parte de los problemas y confusiones.

Dentro de la información literaria que poseemos acerca de los celtas Peninsulares, sin duda es el famoso pasaje de Estrabón III, 4, 16 el que ha gozado de un mayor protagonismo. En él se habla de un supuesto ateismo de los galaicos en comparación con sus vecinos celtíberos quienes danzaban en las puertas de sus casas las noches de plenilunio. Ese supuesto ateismo galaico fue interpretado en base a un carácter anicónico de ese pueblo ${ }^{5}$, algo que sin embargo, no debió de ser así en el mundo celtibérico, muestra de lo cual pueden ser las famosas pinturas polícromas de los vasos de Numancia. De algún modo, la plástica celtibérica nos transmite una profunda sensación de sacralidad encerrada en sus obras, desde las imágenes que inequívocamente representan divinidades, hasta los enigmáticos trísqueles y círculos concéntricos que profusamente decoran su cerámica.

Esas pinturas y esos símbolos nos hablan de un complejo pero muy bien estructurado sistema de creencias, en el que en algunos casos es posible intuir la existencia de algo parecido a un panteón religioso estructurado. Esas imágenes, individuos, animales y símbolos, no hacen otra cosa que materializar la manifestación de entes divinos, haciéndose visibles unas divinidades que son invisibles y

1 ALVAR, J.: «Religiosidad y religiones en Hispania», en ALVAR, J. y BLÁZQUEZ, J. M. a (eds.): La romanización en occidente. Madrid, 1996, pág. 246.

2 LÓPEZ MONTEAGUDO, G.: «La religión céltica, gala y galorromana», en Historia de las Religiones de la Europa Antigua. Madrid, pág. 477.

3 SOPEÑA, G.: Dioses, Ética y Ritos. Aproximaciones para una comprensión de la religiosidad de los pueblos celtibéricos. Zaragoza, 1987, pág. 34.

${ }^{4}$ ENCARNAÇAO, J. de: «A propósito de «religiôes pre-romanas», en ADIEGO, I.; SILES, J. y VELAZA, J. (eds.): Studia Paleohispánica et Indogermánica. J. Untermann ab amicis hispanicis oblata. Aurea Saecula X. Barcelona, 1993, pág. 135.

${ }^{5}$ BLÁZQUEZ, J. M. ${ }^{\text {a: }}$ «Las religiones indígenas del Noroeste de la Península lbérica en relación con Roma», en Imagen y Mito. Madrid, 1977, pág. 376. 
que poseían además rasgos muy personalizados ${ }^{6}$. Evidentemente, no podemos esperar encontrar siempre en el arte celtibérico representaciones de divinidades antropomorfas perfectamente identificables del modo en que se daban en el mundo grecorromano, pues poseían una concepción de lo divino mucho más abstracta. Conocido es el pasaje de Diodoro de Sicilia XXII en el que narra como el caudillo celta Brenos en el santuario de Delfos se mofaba de los griegos por encerrar a sus dioses en estatuas. Los celtas Peninsulares debieron poseer unas ideas religiosas bastante similares, si bien es cierto que sus contactos con el mundo ibéri$\mathrm{co}$, principalmente en el área de la celtiberia, debieron alterar tal percepción. Ese contacto con el mundo lbérico facilitó una creciente asimilación de elementos mediterráneos a lo largo de la segunda mitad del primer milenio a.C., dando lugar a un distanciamiento de la cultura de La Tène y una mayor aproximación a la cultura Ibérica ${ }^{7}$. Esa progresiva aproximación a la estética mediterránea es la que explica la aparición en ocasiones de representaciones de divinidades con carácter antropomorfo, sobre todo ya en momentos tardíos del mundo celtibérico.

Antes de esas representaciones antropomorfas, lo que más hallamos son representaciones de animales, mostrando la intensidad de las relaciones entre estos y las divinidades, bien patente en las imágenes de los dioses que rompen los lazos del antropomorfismo y adoptan características de los animales mismos, tal y como sucede con el famoso dios galo Cernunnos ${ }^{8}$. Esos animales no son pues meras representaciones artísticas, son fruto de una convención plástica que tiende a expresar mediante conceptos finitos términos que aluden a lo que no es tal ${ }^{9}$. Esos animales se perfilan en realidad como símbolos y a veces posteriormente, como atributos de las divinidades antropomorfas.

Realmente, tanto las representaciones zoomorfas como las antropomorfas no dejan de ser símbolos a los que el hombre transporta las características de la divinidad. Como ya explicó brillantemente C. G. Jung «Como hay innumerables cosas más allá del alcance del entendimiento humano, usamos constantemente términos simbólicos para representar conceptos que no podemos definir o comprender del todo. Esta es una de las razones por las cuales todas las religiones emplean lenguaje simbólico o imágenes ${ }^{10}$. Los símbolos creados por celtas y celtíberos nos son especialmente desconocidos y misteriosos, por el hecho de que sabemos muy poco de sus dioses. Del mismo modo que el símbolo de la cruz solo puede interpretarse si se conoce la religión cristiana, los símbolos prerromanos solo los podremos conocer a través de los mitos indoeuropeos y en buena medida, solo a través de las leyendas que han pervivido en el folklore de los pueblos pe-

${ }^{6}$ MARCO, F.: «La religión indígena en la Hispania Indoeuropea», en BLÁZQUEZ, J. M. ${ }^{\text {a }}$ et alii (eds.): Historia de las Religiones de la Europa Antigua. Madrid, 1994, pág. 322.

7 ALMAGRO-GORBEA, M.: «Los celtas en la Península lbérica: origen y personalidad cultural», en ALMAGRO-GORBEA, M. (coord.); ALMAGRO-GORBEA, M. y RUIZ ZAPATERO, G.(eds.): Los Celtas: Hispania y Europa. Madrid, 1993, pág. 150.

8 GREEN, M. J.: «La religión celta», en ALMAGRO-GORBEA, M. y RUIZ ZAPATERO, G. (eds.): Los Celtas: Hispania y Europa. Madrid, 1993, págs. 468-469.

9 SOPEÑA, G.: 1987, op. cit., pág. 47.

10 JUNG, C. G.: El Hombre y sus Símbolos. Madrid, 1966, págs. 20-21. 
ninsulares hasta nuestros días. Tomaremos pues como base para nuestro estudio un análisis iconográfico de los símbolos para poder ahondar en el conocimiento de la religión, pues el arte celtibérico coincide con el resto del arte céltico en que «era un arte cuyo propósito primario era el de ser un vehículo de expresión religiosa» ${ }^{11}$.

El sol, dada la popularidad de su culto desde el mismo Paleolítico ha tenido siempre una gran variedad de símbolos con los que se le ha representado. La distribución de su imaginería en época celta, indica que el dios sol fue adorado en una amplia área que abarca el conjunto de la Europa céltica ${ }^{12}$. La variedad de símbolos con que era representado es muy grande, siendo los principales los motivos soliformes, círculos concéntricos, ruedas radiadas y los trísqueles y tetrásqueles. Todos ellos se pueden hallar representados tanto en objetos funcionales como decorativos, sin duda hablándonos de que el emblema solar tuvo una reconocida función como talismán, para alejar al mal y proporcionar suerte a su poseedor ${ }^{13}$.

Desde la Edad del Bronce podemos hallar en Europa una creciente asociación entre el sol y el caballo. En numerosos mitos sobre el sol, el disco solar era representado sobre un carro tirado por caballos que lo transportaban a través del cielo, caso del carro del dios Apolo ${ }^{14}$, mito que se refleja por ejemplo el famoso carrito de Trundholm, en el que se representa un caballo de bronce tirando de un disco solar. Los rodios adoraron al sol como su principal deidad, y por ello le dedicaban anualmente un carro y cuatro caballos que hundían en el mar, pensando que después de un año de incesante trabajo los anteriores estarían ya estropeados ${ }^{15}$. También en el Rig Veda aparece el carro del sol tirado por un caballo, Etaça (VII, 63, 2) o es el sol mismo a veces un caballo semental $(\mathrm{VII}, 77,3)^{16}$, lo que explica que en ocasiones el sol no se represente como un carro sino como el propio caballo, ayudando a entender el siguiente ejemplo. Se trata del bronce de Calaceite (Teruel), interpretándose este como un thymiaterion formado por círculos que unidos forman uno superior a modo de símbolo solar y en cuyo fuste se inserta la figura de un caballo, fue hallado en una tumba de guerrero junto a una coraza también adornada con círculos, indicándonos que el candelabro de Calaceite pudo tener una función religiosa en la que se relacionan caballo y sol con las ideas de ultratumba ${ }^{17}$. El culto al sol se hallaba muy extendido entre los pueblos de la meseta, apareciendo representaciones suyas de manera habitual en las urnas funerarias de Las Cogotas, donde volvería a resaltar su vinculación con la ultratumba, espadas, adornos, etc. ${ }^{18}$. Son especialmente llamativas unas barcas votivas de cerámica decoradas

11 GREEN, M. J.: Arte Celta. Leyendo sus Mensajes. Madrid, 2007, pág. 9.

12 GREEN, M. J.: The Sun Gods of Ancient Europe. Londres, 1991, pág. 89.

13 GREEN, M. J.: op. cit., pág. 70.

14 GREEN, M. J.: Mitos Celtas. Madrid, 1995, pág. 51.

15 FRAZER, J. G.: La Rama Dorada. Magia y Religión. Méjico, 1981, pág. 109.

16 ELIADE, M.: Tratado de Historia de las Religiones. Morfología y Dialéctica de lo Sagrado. Madrid, 1981, pág. 160.

17 BLÁZQUEZ, J. M.a.: “Cultos solares en la Península lbérica: el caballito de Calaceite», en $V$ Congreso Nacional de Arqueología. Zaragoza, 1957, pág. 184.

${ }_{18}$ BLÁZQUEZ, J. M. ${ }^{\text {a: }}$ «La religión de los pueblos de la Hispania Prerromana». Zephyrus 43, 1990, pág. 231. 
con círculos concéntricos, que fueron halladas en el diferentes yacimientos del área vaccea, generalmente en las necrópolis ${ }^{19}$.

La abundancia de representaciones de la segunda Edad del Hierro en las que el caballo aparece asociado a motivos solares, algo común en las monedas del mundo celta y especialmente abundantes en la Galia, sugiere que el caballo llega a convertirse en una imagen solar en sí mismo ${ }^{20}$ y que aparece en ocasiones como un sustituto de los demás símbolos solares. Como ya señaló Blázquez, aquí en España no hay monedas que representen caballos rodeados de discos, pero hay fíbulas con forma de caballo que se suelen representar cubiertos de círculos ${ }^{21}$. Este tipo de fíbulas ampliamente difundidas, desde el valle del Ebro hasta Extremadura y desde León a Cuenca ${ }^{22}$, han sido tradicionalmente puestas en relación con unos ejemplares italianos del área circumalpina, de cronología varios siglos anterior a los ejemplares hispanos, pero que podrían en efecto estar reflejando un fondo mítico común ${ }^{23}$. Ese mito compartido no es otro que el de «el carro de Apolo", que pasó de ser tirado por aves a serlo por caballos ${ }^{24}$, lo cual se sostiene perfectamente por un pequeño grupo de fíbulas italianas que representan un carro con auriga tirado por caballos y precedido por un ave, mostrando la progresiva transformación del mito.

Por lo tanto, el jinete y el caballo de las fíbulas hispanas debieron poseer un sentido mágico, posiblemente asociado a algún pasaje mítico relacionado con una divinidad solar y de la guerra ${ }^{25}$, algo que no era exclusivo de la antigua Hispania, puesto que la divinidad solar con carácter ecuestre está ampliamente difundida por el mundo celta, como muestran las numerosas columnas gigantes de Júpiter del área del Rin, en las que se representa un dios jinete solar con claro carácter céltico sincretizado con el Júpiter romano ${ }^{26}$.

Este dios jinete celeste/solar que es representado en las fíbulas hispanas, aparece también representado en las monedas celtibéricas, no solo en los casos en los que aparece portando una palma como señaló Salinas de Frías ${ }^{27}$, sino también y más especialmente si cabe, en aquellas que aparece armado con lanza, modelo que parece derivar de las acuñaciones de Hierón II de Siracusa ${ }^{28}$. Pese a que el tipo

19 WATTENBERG, F.: «Las barcas solares del círculo vacceo». Pyrenae 2, 1966, págs. 51-66 passim.

20 GREEN, M. J.: The Gods of the Celts. Gloucester, 1986, pág. 59.

21 BLÁZQUEZ, J. M. a.: 1957 op. cit., pág. 189.

22 ALMAGRO-GORBEA, M. y TORRES, M.: Las fíbulas de jinete y de caballito. Aproximación a las elites ecuestres y su expansión en la Hispania céltica. Zaragoza, 1999, pág. 25.

${ }^{23}$ ALMAGRO-GORBEA, M. y TORRES, M.: op. cit., págs. 51-52.

24 ALMAGRO-GORBEA, M. y TORRES, M.: op. cit., pág. 70.

25 ALMAGRO-GORBEA, M. y TORRES, M.: op. cit.

26 GREEN, M. J.: 1991 op. cit., pág. 59.

27 SALINAS DE FRIAS, M.: «El toro, los peces y la serpiente: algunas reflexiones sobre iconografía y la religión de los celtíberos en su contexto histórico", en ALVAR, J. y MANGAS, J. (eds.): Homenaje a José Ma. Blázquez, Vol. II. Madrid, 1994, págs. 515-517.

28 ALMAGRO-GORBEA, M.: “Iconografía numismática hispanica: jinete y cabeza varonil», en GARCÍA BELLIDO, M. P. y SOBRAL R. M. (eds.): La moneda hispánica, ciudad y territorio. AAEA 14. 1995, pág. 58. 
iconográfico de las monedas celtibéricas derive de modelos mediterráneos, fueron adaptados por el mundo ibérico y posteriormente el celtibérico, que las incorporaron a su propio sistema socio-ideológico dándoles un significado pleno para ellos y fácilmente comprensible ${ }^{29}$. Ese elemento de imitación de modelos de las monedas es común al resto del mundo celta, donde también fueron objeto de una «interpretatio céltica», mostrando en muchos casos deidades bajo nombres locales ${ }^{30}$.

A la vista de los datos, nos encontramos en situación de apoyar la hipótesis de que las abundantes imágenes del jinete a caballo que aparecen en el mundo indoeuropeo peninsular, están representando a su divinidad celeste/solar, que sin duda por la cantidad de los ejemplos, debió ser la principal de su panteón. El análisis de su iconografía nos revela aspectos de esta divinidad que serán tratados a continuación, manifestando un amplio radio de actuación que comprendía tres funciones principales: la guerra; la distribución de la fertilidad y por último pero no menos importante, la muerte y el mundo funerario.

\section{LA FUNCIÓN GUERRERA DEL DIOS SOLAR}

La iconografía de la divinidad solar nos habla de una primera función, la del dios celeste como un gran guerrero protector de la humanidad. Todo parece indicar que los símbolos solares debieron tener una función de talismanes ${ }^{31}$ y el símbolo del caballo y el jinete no fue menos. Dentro de las fíbulas de caballito existe un grupo que se caracteriza por poseer anillas, elemento que además de poseer una función decorativa debió poseer una función apotropaica basada en el tintineo que producirían con el movimiento ${ }^{32}$. Ese tintineo estaría pensado para alejar los malos espíritus del portador de la fíbula, y es que esa lucha de la divinidad contra los espíritus nocivos sería una de sus principales cometidos. Así se ve reflejado en la figura del dios Thor, quien con su martillo protege al mundo de los gigantes, o el dios Indra, que con sus rayos protege a la humanidad de la amenaza de Vrtra y otros demonios ${ }^{33}$, o también como se desprende de la figura del Wacilla de los osetas, divinidad celeste dueña del rayo que no deja de circular por el cielo cazando los espíritus malhechores ${ }^{34}$.

El rayo se revela como la principal arma del dios del cielo, empleada tanto para castigar a los espíritus malignos como en ocasiones a los propios hombres, así el Júpiter romano castigaba con su rayo a aquellos que faltaban a su palabra o violaban un pacto ${ }^{35}$, mostrando cómo ésta divinidad también actuaba como protectora de los pactos, algo que posiblemente sea extensible a la divinidad suprema cel-

29 ARÉVALO, A.: «La moneda hispánica del jinete Ibérico: estado de la cuestión», en QUESADA SANZ, F. y ZAMORA MERCHAN (eds.): El caballo en la antigua lberia. Madrid, 2003, pág. 67.

30 ALLEN, D.F.: The Coins of the Ancient Celts. Edimburgo, 1980, págs. 130 ss.

${ }^{31}$ GREEN, M. J.: 1986, op. cit., pág. 40.

32 ALMAGRO-GORBEA, M. y TORRES, M.: 1999, op. cit., pág. 23.

33 DUMÉZIL, G.: Los Dioses de los Indoeuropeos. Barcelona, 1970, pág. 27.

34 DUMÉZIL, G: Escitas y Osetas. Mitología y Sociedad. Méjico, 1996, pág. 63.

35 ELIADE, M.: 1981, op. cit., págs. 99-100. 
tibérica. Odín y Lug son también divinidades celestes que emplean la lanza como arma. La Gai Bolga era la lanza argéntea del dios Lug y se decía que ninguna batalla había sido nunca ganada contra quien la empuñase en su mano ${ }^{36}$. Esta posesión por parte de la divinidad de un arma que garantiza la victoria nos lleva a contemplar otro curioso aspecto del dios, su capacidad para interactuar con los hombres enviándoles objetos, especialmente armas, desde el cielo. Todo indica que entre los pueblos del centro de la Península existía tal creencia, pudiendo los dioses enviar objetos o animales a las personas a las que la divinidad dispensaría una protección especial ${ }^{37}$. Esto último queda perfectamente reflejado en el pasaje del escritor romano Floro $(I, 33,14)$ acerca de la revuelta del caudillo numantino Olíndico: «Olyndicus, qui hastam argenteam quatiens quasi caelo missam uaticinati similis omnium in se mentes conuerterat».

Esa lanza que el cielo envía a Olíndico recuerda extraordinariamente a la lanza de Lug, que además es símbolo del rayo ${ }^{38}$. Las llamadas piedras «de rayo» son generalmente piedras talladas prehistóricas que se pensaba eran puntas de relámpagos y como tales eran veneradas y conservadas ${ }^{39}$, mostrando una antiquísima identificación entre rayo y lanza. La victoria le debía ser dada a Olíndico no por la creencia de que esa lanza era un arma superior sino porque el propio arma así lo significaba. En el mundo germano era la lanza de Odín Gungnir la que otorgaba la victoria y de hecho en diversas fuentes se recoge la existencia de una práctica ritual que consistía en lanzar una lanza por encima de los enemigos antes de un combate, para propiciar el favor de Odín y conseguir la victoria ${ }^{40}$. Quizá esta práctica explique porqué Olíndico pudo vaticinar la victoria cuando recibió la lanza, pues el mensaje de triunfo debía ser obvio para él.

Por otra parte, esa función de protector contra los malos espíritus de la divinidad solar, se relaciona estrechamente con otra de sus funciones, la de sanador y protector contra las enfermedades.

Es un hecho conocido que en la antigüedad las enfermedades eran vistas como demonios o malos espíritus que se colaban en el cuerpo de los hombres y les causaban mal, por ello para los hititas por ejemplo, cualquier proceso de curación entraba dentro del terreno de la magia ${ }^{41}$. De hecho, en el texto de "Oración a Kantuzili para aliviar sus sufrimientos", se halla a ese personaje, posiblemente un príncipe, rogando al dios del sol que lo libre de su enfermedad ${ }^{42}$. En el mundo galorromano, la divinidad guerrera Marte era invocada como un guerrero que lucha-

36 OLMSTED, G.: The Gods of the Celts and the Indoeuropeans. Budapest, 1994, pág. 117.

37 BLÁZQUEZ, J. M.: Religiones Primitivas de Hispania I. Fuentes literarias y epigráficas. Madrid, 1962, pág. 11

${ }^{38}$ MARCO, F.: «La religión de los celtíberos», en I Symposium sobre los Celtíberos. Zaragoza, 1987, págs. $69-70$.

39 ELIADE, M.: op. cit., págs. 76-77.

40 ELLIS DAVIDSON, H. R.: Gods and Myths of Northern Europe. Harmondsworth, 1969, pág. 53.

41 ÁLVAREZ-PEDROSA, J. A.: «Mundo simbólico y sugestión ritual: magia y curación en los textos hititas", en Actas del III Congreso Español de Antiguo Oriente Próximo. Huelva 2003. Huelva Arqueológica 19, 2004, pág. 100 ss.

42 GARCÍA TABAZO, J. V.: Textos Religiosos Hititas. Mitos, Plegarias y Rituales. Madrid, 2002, pág. 275. 
ba contra la enfermedad, y de hecho poseyó santuarios curativos como el de Marte Lenus en Trier ${ }^{43}$, mostrando la conexión entre guerra y curación como un proceso común en el que se vence a los espíritus enemigos que causan mal. Especialmente significativa fue en el contexto de las curaciones, la conjunción de sol y agua, a los que se otorgaba un poder regenerativo con gran capacidad de curación ${ }^{44}$, algo que también trataremos durante el análisis de la divinidad solar en su rol fertilizador.

El carácter guerrero de la divinidad suprema tiene su origen probablemente en la primera gran batalla de carácter iniciático que ha de superar. En todas las mitologías indoeuropeas, el mundo es creado tras la derrota de un gran monstruo, que en ocasiones retiene las aguas del mundo impidiendo el surgimiento de la vida. Este mito aparece de diversas maneras pero el concepto subyacente es que el dios del cielo y el rayo se ha de enfrentar y vencer al terrible monstruo que amenaza con la destrucción de la humanidad ${ }^{45}$. Es de este modo como el dios Júpiter es representado en las columnas gigantes del Rin, como un jinete empuñando el rayo, venciendo a las fuerzas de la oscuridad en forma de monstruo semi-zoomorfo ${ }^{46}$. Un mito de características similares, lo encontramos representado en una estela funeraria de Clunia (Fig. 1) que analizamos a continuación.

La estela en cuestión se halla representada por sus dos caras, en las que posee escenas diferentes. En la primera cara hallaremos una alegoría del cielo nocturno y en la segunda del cielo diurno, concretamente del amanecer. En la cara que simboliza la noche, aparecen representados cinco elementos, un bóvido, un cánido, dos peces y una serpiente aparentemente con dos cabezas que enmarca el conjunto. No cabe duda de que el bóvido es una representación de la luna y de hecho aparece con los cuernos muy destacados mostrando la relación entre éstos y el creciente lunar, lo cual es muestra de un culto a los poderes creativos y fecundadores de la naturaleza, además de ser un símbolo de regeneración periódica ${ }^{47}$.

En segundo lugar podemos observar que aparece un cánido, probablemente un lobo, sobre el bóvido en actitud de atacarlo. Esta escena recuerda extraordinariamente al mito germano que explicaba el movimiento del sol y la luna por el hecho de ser perseguidos por lobos y que Snorri Sturluson recogió en sus Eddas (Gylfaginning XII). Cada mes un lobo muerde a la luna, pero se escapa y crece otra vez recuperando la parte perdida ${ }^{48}$. Con este mito o uno muy similar debieron explicar los antiguos celtas hispanos el porqué de las fases de la luna. El lobo, por sus características de animal cazador de hábitos nocturnos, que con frecuencia ataca los rebaños de los pastores, debió ser contemplado por aquellas sociedades ganaderas como un animal paradigma del caos, la muerte, la guerra y como no, la noche.

${ }^{43}$ GREEN, M. J.: Symbol and Image in Celtic Religious Art. Londres, 1989, pág. 115.

44 GREEN, M. J.: 1991, op. cit., pág. 107.

45 ELLIS DAVIDSON, H. R.: op. cit., pág. 90-91.

46 GREEN, M. J.: op. cit., pág. 95.

47 GIMBUTAS, M.: The goddesses and Gods of Old Europe. Myths and Cult Images. Londres, 1989, pág. 91

48 ELIOT, A.: Mitos. Barcelona, 1976, pág. 80. 


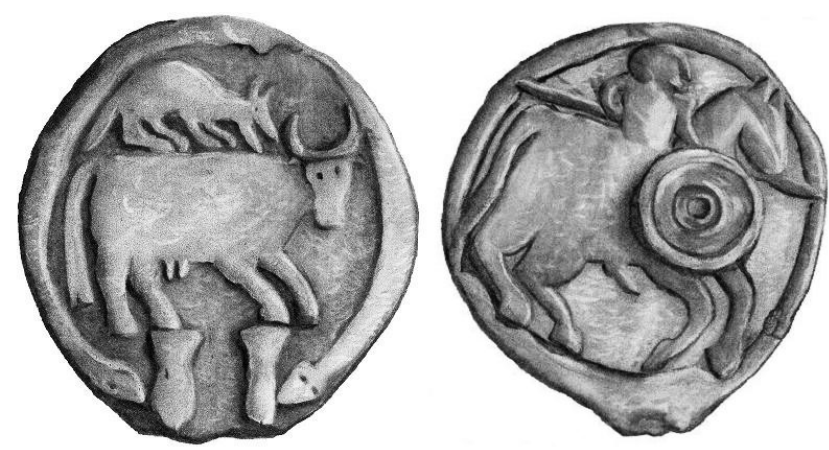

Fig. 1.

El tercer elemento que llama nuestra atención es una gran serpiente con dos cabezas que se halla en ambas caras de la estela enmarcando las escenas. Algunos autores romanos describieron a esta serpiente bicéfala como un animal supuestamente real con el nombre de anfisbena y en la iconografía aparece desde el mundo micénico representado en brazaletes. En la Península lo podemos hallar representado en las pulseras de plata del tesoro celtibérico de Padilla de Duero (Valladolid) ${ }^{49}$ y también dando forma a la Lúnula de Châo de Lamas (Miranda do Corvo, Conimbriga). La serpiente bicéfala también aparece en ocasiones representada en las estelas funerarias como la de Coemea Desica, que al igual que en la estela que nos ocupa, aparece rodeando por completo la representación ${ }^{50}$.

Según el trágico griego Esquilo, Argos o Argus es el guardián de lo, la virgen cornuda, a la que también se representa como una vaca, y en la que los gramáticos griegos reconocieron la personificación de la luna. La noche personificada por Argos, es el vigilante guardián a cuyo cuidado ha sido confiada la luna, la vaca errante. Algo similar se observa en la mitología irlandesa, donde el dios cornudo Buar-ainech, que representaba la luna divinizada, era custodiado por su propio hijo Balor, que también es una personificación de la noche ${ }^{51}$. En nuestra estela, Balor o Argos está representado por el anfisbena que custodia la imagen del bóvido enmarcándola, y es que la serpiente en el mundo indoeuropeo en ocasiones es símbolo de lo caótico, como el monstruo Tifón que derrota Zeus, representado con miembros de serpiente o el monstruo serpentiforme que también aparece representado en las columnas gigantes de Júpiter del Rin. También la serpiente Pitón fue matada por Apolo; en la mitología escandinava lormungander es derrotada por Thor; Vrtra es vencida por Indra en los textos hindúes y fuera del mundo indoeuropeo, la serpiente Apofis es vencida por Ra cada mañana en alegoría de la victoria de la luz sobre las tinieblas.

49 CURCHIN, L. A.: «Mitología celtibérica: El problema de las bestias fantásticas», Kalathos 22-23, 2003-04, págs. 189-191.

50 OSABA, B.: Simbolismo en la ornamentación de las estelas hispanorromanas del Museo Arqueológico de Burgos. Burgos, 1958, pág. 10.

51 D'ARBOIS de JUBAINVILLE, H.: El Ciclo Mitológico Irlandés y la Mitología Céltica. Barcelona, 1986, págs. 132-133. 
En la mitología irlandesa, es el dios solar Lug quien mata al gigante de un solo ojo Balor, de una pedrada con su honda, del mismo modo que David con Goliat. En la mitología griega, Argos es llamado Panoptes y «el de los cien ojos» porque simboliza la noche estrellada. Argos también fue matado de una pedrada, en este caso lanzada por Hermes, de hecho en la lliada, Hermes es apodado «matador de Argos" y Lug es el Hermes céltico ${ }^{52}$, el Mercurio que según César era la principal divinidad de los galos (César, B.G. VI, 17).

En el anverso de nuestra estela cluniense contemplamos pues una representación alegórica de la noche, con la luna representada por el bóvido que está siendo devorada por el lobo, y todo ello rodeado por la representación de la noche estrellada en forma de serpiente de dos cabezas.

En el reverso se representa un jinete a caballo superpuesto a la figura de la serpiente que de nuevo enmarca la escena. Del mismo modo que en el resto de mitologías el dios de la luz vence a la serpiente, también en el mundo celtibérico debió existir ese mitologema, claramente representado en esta imagen, en la que el jinete se impone a la serpiente acabando con la noche y dando comienzo al día. Es por tanto probable que el dios jinete hispano, muy posiblemente Lug a la vista de los datos, fuese identificado con el Mercurio romano en base a este mito del que se desprende la idea del dios celeste vencedor del caos y la noche.

Por lo tanto, podemos señalar que en esta estela funeraria se están representando mitos a cerca de las concepciones que aquellas gentes tenían acerca del curso de los astros y las transformaciones que sufre el cielo cada día. Nos habla también de la cíclica victoria de la luz sobre las tinieblas y de la vida sobre la muerte, en clara referencia a que del mismo modo también el difunto acabará venciendo sobre la muerte y alcanzará una nueva vida.

\section{LA DIVINIDAD SOLAR EN SU ROL FERTILIZADOR}

Es casi universal la creencia en un ser divino celeste, creador del universo y garante de la fertilidad de la tierra mediante el derramamiento de la lluvia ${ }^{53}$ dado que las emanaciones del cielo, sol y lluvia, fueron símbolo de vida para las sociedades agrícolas primitivas ${ }^{54}$.

Es posible que el rayo fuese visto como un instrumento con el cual el sol inducía la lluvia ${ }^{55}$ y se la proporcionaba como alimento a su consorte la Tierra ${ }^{56}$. De hecho, es frecuente que en el mundo indoeuropeo sea el dios del rayo el encargado de proporcionar la lluvia, caso de Indra, que por su poder genésico es llamado Sahsramushka, «el de los mil testículos» (Rig Veda VI, 64, 3)57; Thor, a quien

2 D'ARBOIS de JUBAINVILLE, H.: op. cit., págs. 131-132.

3 ELIADE, M.: op. cit., pág. 62.

4 GREEN, M. J.: 1986, op. cit., pág. 39.

55 GREEN, M. J.: 1991, op. cit., pág. 94

56 OLMSTED, G.: op. cit., pág. 101.

57 ELIADE, M.: op. cit., págs. 104 ss. 
también se invocaba para que dosificase las lluvias y evitase el hambre ${ }^{58}$, o Zeus, que según Pausanias $(I, 32,2)$ poseía un santuario dedicado a Zeus Ombrios, «Zeus el dios de la lluvia»59.

En numerosas culturas, y quizá así sucedía en la celtibérica, el ritual de imprecación de la lluvia era un ritual en el que intervenía la sangre, pues por magia homeopática se tendía a identificar la sangre con la lluvia, y si la primera se producía y corría en abundancia, la lluvia también lo haría ${ }^{60}$. Por este motivo el sol también era visto como un cazador que fertilizaba la tierra derramando la sangre de sus víctimas ${ }^{61}$.

El tema de la caza divina aparece en la Península Ibérica bajo la forma de la caza del jabalí. Este mito aparece representado en una serie de fíbulas de caballito que incluyen un estilizado jabalí en la parte frontal, catalogadas como el grupo E4 según M. Almagro y M. Torres ${ }^{62}$ y bien estudiadas por A. Esparza, quien cataloga unas dieciséis fíbulas, poniéndolas en relación con las monedas célticas que habitualmente representan a ambos animales ${ }^{63}$. Por otra parte existe un segundo grupo de fíbulas que también nos muestran la representación del mismo mito, de un modo más narrativo y menos esquemático, el denominado grupo de «fíbulas ibéricas con escenas venatorias». Este grupo fue estudiado por C. Angoso y E. Cuadrado, atribuyéndolas una cronología de entre los siglos III a I a.C. aproximadamente ${ }^{64}$, coincidiendo en buena medida con la cronología de los ejemplares meseteños, que serían algo anteriores ${ }^{65}$. Este grupo de fíbulas muestra en su representación a un jinete a caballo persiguiendo a un jabalí acompañado de un perro y dos en el ejemplar de Los Almadenes de Pozoblanco (Córdoba), que también se diferencia del resto por no poseer la figura del jinete ${ }^{66}$. En los ejemplares de Muela de Taracena (Guadalajara) y Chiclana del Segura (Jaén), aparece representado en la parte posterior de la fíbula una deidad femenina entre prótomos de caballo que posiblemente represente a la diosa de la fecundidad de la tierra, esperando que caiga la sangre del jabalí sobre ella en forma de lluvia, para ser fertilizada y proporcionar abundancia a la humanidad.

Otro lugar donde aparece representada la cacería del jabalí es en los famosos grabados rupestres del castro de Yecla, en Salamanca, donde aparecen representados unos jinetes armados con lanza acosando a unos jabalíes ${ }^{67}$, en lo que pudiera ser realmente una práctica de cacería ritual para propiciar las lluvias. Pero sin

58 DUMÉZIL, G.: 1970, op. cit., pág. 26

59 GREEN, M. J.: 1991, op. cit., pág. 123.

60 FRAZER, J. G.: 1981, op. cit., págs. 92-93.

61 GREEN, M. J.: 1991, op. cit.

62 ALMAGRO-GORBEA, M. y TORRES, M.: op. cit., pág. 23.

${ }^{63}$ ESPARZA, A.: «Cien años de ambigüedad: sobre un viejo tipo de fíbulas de la Edad del Hierro de la Meseta Española». Zephyrus 44-45, 1991-92, passim.

${ }^{64}$ ANGOSO, C. y CUADRADO, E.: «Fíbulas ibéricas con escenas venatorias». BSAarq 13, pág. 29.

65 ARGENTE, J. L.: Las fíbulas de la Edad de Hierro en la Meseta Oriental. Valoración tipológica, cronológica y cultural. EAE 168, Madrid, 1994, pág. 94.

66 ANGOSO, C. y CUADRADO, E.: op. cit., págs. 23-24.

${ }^{67}$ ÁLVAREZ-SANCHÍS, J. R.: Los Señores del Ganado. Arqueología de los pueblos prerromanos del occidente de Iberia. Madrid, 2003, pág. 89. 
duda el mejor ejemplo con el que podemos conectar la imagen de la cacería, con el mito de producción de la lluvia, es a través del llamado «Carrito de Mérida» (Fig. 2). Este carrito votivo se compone de una plataforma de cuatro ruedas sobre cuya caja se representa la escena del jinete acompañado de un perro (probablemente fueron dos) persiguiendo a un jabalí. De la parte posterior de la caja debieron colgar suspendidos cinco cencerros de los que solo quedan dos. José María Blázquez ya relacionó este tipo de carro con otros ejemplos peninsulares y europeos, señalando que estaría probablemente consagrado al sol, como mostrarían los círculos concéntricos representados a lo largo de la caja del carro, y relacionado con rituales de imprecación de lluvias, a través del tintineo que producirían los cencerros al moverse el carro ${ }^{68}$, Blázquez da una cronología para este carro de entre los siglos IV-III a.C. lo que nos hace pensar, que no debió ser antes del siglo IV a.C. cuando las sociedades peninsulares plasmaron figurativamente la imagen del dios celeste-solar como un jinete cazador. Se trata sin duda de un carro que debió ser empleado en ceremonias religiosas y ser objeto directo de culto. La manera de tributar culto a la divinidad consistiría simplemente en mover un poco el carro y hacer sonar los cencerros, de un modo análogo a como se tributaba culto al carro de Thor de Trandheim, y al que solo había que mover un poco tirando de una cuerda para tributar culto al dios ${ }^{69}$. De hecho, el carrito de Almorchón, pese a que no muestra la imagen de la cacería, solo al jinete a caballo, también posee dos anillas en la parte anterior para enganchar una cadeneta o una cuerda ${ }^{70}$, y así poder realizar el acto de culto al modo del carro de Thor.

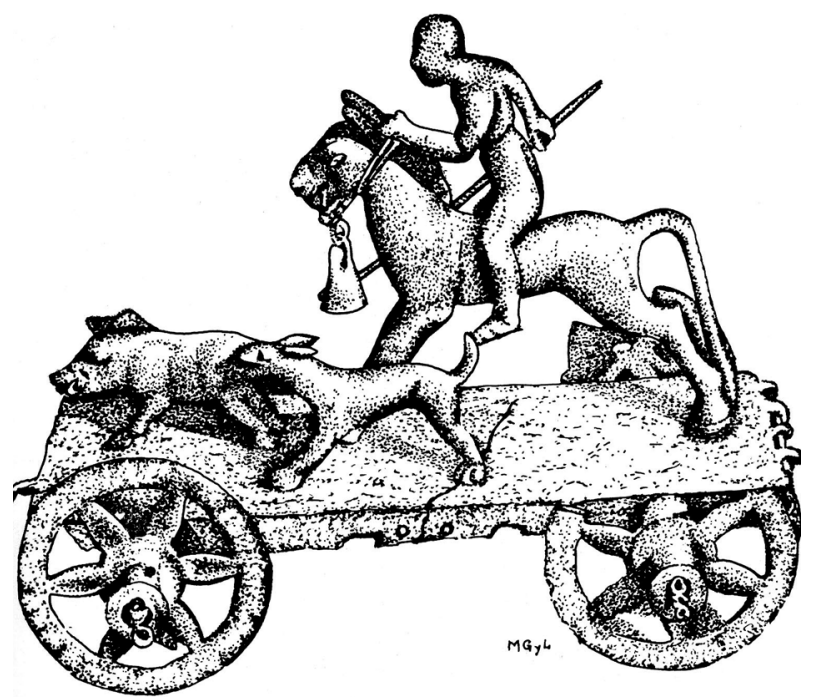

Fig. 2.

68 BLÁZQUEZ, J. M. a: “Los carros votivos de Mérida y Almorchón», en BLÁZQUEZ, J. M.a. Imagen y mito. Estudio sobre las religiones mediterráneas e ibéricas. Madrid, 1977, págs. 345 ss.

69 ELLIS DAVIDSON, H. R.: op. cit., págs. 75-76.

70 MÉLIDA, J. R.: Catálogo monumental de España: provincia de Badajoz (1907-1910), Vol. I. Madrid, 1925, págs. 78-79. 
Es posible que el jabalí de las representaciones que estamos tratando también representase, de forma zoomorfa, a algún tipo de divinidad relacionada con la fertilidad y el agua, que podría ponerse en conexión con las estatuas de verracos del área vettona. La divinidad jabalí sería en general una divinidad benefactora que habitualmente se encargaría de dispensar las lluvias, pero que en cierto momento dejase de hacerlo, pasando a pedirse, por parte de los fieles, la intermediación de la divinidad solar. Este mitologema se puede recoger en varios mitos del mundo indoeuropeo. Por ejemplo en el mundo hitita, hallamos el mito de Telipinu, divinidad de la tempestad y la fertilidad que se enfureció y se escondió produciendo hambre a la humanidad, teniendo que ser el dios sol quien organizase su búsqueda, hasta que finalmente es encontrado por una abeja que envía la diosa madre Hannahanna ${ }^{71}$. Más claro queda en el ritual de imprecación de lluvias de los Osetas quienes en caso de que el dios de la lluvia no escuchase sus plegarias, pedían la intermediación del dios principal Tyxost para que interviniese y se produjese la ansiada lluvia ${ }^{72}$.

En Mérida se halló un ara dedicada a la divinidad Sigerio Stillifero, nombre que parece compuesto por la raíz sig- sigis «victoria» y el epíteto latino relacionado con stilla-ae «gota» y el verbo stillare «gotear» ${ }^{73}$. Esta divinidad ya fue señalada por Albertos como un posible dios de la lluvia y el ara fue hallada en el cerro de San Albín, junto a otra dedicada a Mithra, divinidad solar por excelencia, en lo que pudo ser un templo dedicado al dios ${ }^{74}$, por lo que podríamos hallarnos ante un claro ejemplo de sincretismo entre la divinidad jinete-solar peninsular y el dios sol oriental Mithra.

El cerdo y el jabalí están en el mundo celta estrechamente vinculados a la idea de regeneración, así por ejemplo, los cerdos mágicos de Manannan, eran símbolos de regeneración, pues podían matarse y comerse un día y estar vivos de nuevo al día siguiente, listos para ser sacrificados de nuevo ${ }^{75}$. En cierto modo, esos cerdos, por su supuesta capacidad regenerativa y su vinculación a un dios del mar, podrían estar sugiriendo una semejanza con las nubes, como si éstas fueran vistas como cerdos o jabalíes, listos para ser cazados y derramar la lluvia. En la leyenda castellana de «Fernán González y el puerco montés», recogida por L. Díaz Viana ${ }^{76}$, se menciona un vaticinio realizado por un monje de un monasterio a Fernán González, en el que se le augura una victoria frente a los moros tras producirse un curioso fenómeno: «Las nubes se arremolinarán sobre los combatientes en forma de un jabalí y un caballero que lo persigue» ${ }^{77}$. Esta leyenda recoge esa antigua creencia de nubes con forma de jabalí, perseguidas por un cazador que finalmente derramará la lluvia y fertilizará la tierra. Es posible que esa figura del dios jabalí, como

71 GARCÍA TRABAZO, J. V.: 2002, op. cit., págs. 105-139.

72 DUMÉZIL, G.: 1996 op. cit., pág. 66.

73 ALBERTOS, M. L.: «Nuevas divinidades de la antigua Hispania». Zephyrus 3, 1952, pág. 61.

MÉLIDA, J. R.: 1925 op. cit., pág. 206.

5 GREEN, M. J.: 1995, op. cit., pág. 18.

76 DÍAZ VIANA, L.: Leyendas Populares de España. Históricas, Maravillosas y Contemporáneas. Madrid, 2008, págs. 83-86.

77 DÍAZ VIANA, L.: op. cit., pág. 84. 
dios de las nubes, sea el Nuberu de las leyendas asturianas. Nos han llegado varios conjuros para tratar de disipar la niebla en los que básicamente se amenaza al Nuberu con que va a venir San Juan o «Xuan blancu» (el sol) montado en su caballo y acompañado de su perro, en ocasiones se dice que es ayudado por la virgen o bien que es acompañado por su «mujer barbuda», y que San Juan se lo va a comer ${ }^{78}$, leyenda que es inevitable comparar con las imágenes de las fíbulas ibéricas de escena venatoria, en las que el jinete y sus perros persiguen al jabalí acompañados por la representación de la diosa de la fertilidad y la tierra. También aparece la figura del cazador divino en la épica galesa, concretamente en el Libro Rojo de Hergest, donde aparece con el nombre de Mabon, un cazador cautivo liberado por los héroes Culhwch y Arturo, para que de caza al jabalí mágico Twrch Trwyth. ${ }^{79}$. La figura de Mabon, como ya veremos está también relacionada con el carácter funesto de la divinidad jinete.

Es a través de la asociación de sol y lluvia, a través de la cual la divinidad suprema puede actuar con un rol fertilizador, necesita de la intervención de este otro elemento para ser efectivo. Del mismo modo es también habitual una segunda asociación, la del matrimonio del dios supremo con la diosa de la fertilidad que conjugaba el principio masculino de la sociedad con el principio femenino de la naturaleza para garantizar la prosperidad del pueblo80. Este debió ser por ejemplo el caso de Júpiter Liber, antiquísima divinidad agrícola que compartía templo a los pies del Aventino con su paredra Ceres $^{81}$, o el del primitivo Poseidón griego «Poseidas», dios del caballo, las aguas dulces y el mundo subterráneo, que se emparentaba con Demeter bajo la apariencia de un caballo ${ }^{82}$. Sin embargo, la divinidad celeste por sí sola también podía relacionarse con la fertilidad, no como un productor, sino como un guardián. Esta función podría también encuadrarse dentro del ámbito de la función guerrera del dios, pues su labor no es otra que la de actuar como guardián de los campos, protegiendo las cosechas de los demonios que la perjudicaban. Por esa labor, era habitual que al final de la época de la cosecha se celebrase un festival en honor de la divinidad protectora. Así por ejemplo hallamos el festival del October Equus celebrado en Roma cada quince de octubre, en el que se daba gracias a Marte por proteger el grano ${ }^{83}$, el festival del Xory bon que los osetas celebraban en honor de Wacilla ${ }^{84} \mathrm{o}$ la fiesta de Lugnasad cada primero de Agosto en honor del dios Lug, patrón también de los primeros frutos ${ }^{85}$. En la Galia en ocasiones aparecen enterramientos de caballos, a veces con hombres, en el in-

78 LLANO ROZA DE AMPUDIA, A. de: Del Folklore Asturiano. Mitos-Supersticiones-Costumbres. Oviedo, 1972, págs. 14 ss.

79 GREEN, M. J.: Dictionary of Celtic Myth and Legend. Nueva York, 1992, pág. 137.

80 SJODESTEDT, M. L.: Gods and Heroes of the Celts. Londres, 1949, págs. 93-94.

81 MARTÍNEZ-PINNA, J. y MONTERO, S.: «La religión de los pueblos itálicos», en BLÁZQUEZ, J. M. ${ }^{a}$ et alii (eds.): Historia de las Religiones de la Europa Antigua. Madrid, 1994, pág. 114.

82 RAMOS FERNÁNDEZ, R.: «El caballo como divinidad ibérica», en ADIEGO, I. J.; SILES, J. y VELAZA, J. (eds.): Studia Paleohispánica et Indogermánica. J. Untermann ab Amicis Hispanicis Oblata. Aurea Saecula X. Barcelona, 1993, págs. 270-271.; OLMSTED, G.: op. cit., pág. 73.

83 DUMÉZIL, G.: 1970 op. cit., págs. 31-32.

84 DUMÉZIL,G.: 1996 op. cit., pág. 65.

85 OLMSTED, G.: op. cit., pág. 118. 
terior de silos $^{86}$, quizá como consecuencia de rituales de agradecimiento o propiciación de la divinidad protectora, que cuida del grano y lo protege para que no sufra ningún daño, con un objetivo similar al que tenía el October Equus.

El mito de la caza divina aparece a menudo representado en estelas funerarias, principalmente estelas discoideas de época romana, en un contexto funerario que a priori queda muy lejos de un mito de carácter fertilizador. El jabalí es un animal que frecuentemente se vincula a las creencias de ultratumba, haciendo del tema de su caza una imagen típicamente funeraria ${ }^{87}$. Este no sería un caso aislado de un elemento que pasa de tener un simbolismo relacionado con la fertilidad, a cobrar un significado funerario, pues parece que el huevo también fue originariamente un símbolo de fertilidad que acabó convirtiéndose en un emblema de resurrección ${ }^{88}$. Un proceso similar sucedió con el tema de la caza divina, que en las estelas funerarias se vinculó a una posible idea de "resurrección» a una nueva vida, similar a la que experimentan las plantas con el agua fertilizadora de la lluvia. También hay que señalar, que la caza divina no deja de ser la narración del triunfo de de la luz sobre las oscuras nubes que llevan la noche al día cuando ocultan al astro, por lo que las estelas funerarias siguen presentando el triunfo de la luz y de la vida frente a las tinieblas de la muerte. Esta asociación de la divinidad celeste con el mundo funerario no es en absoluto fortuita, pues tuvo un rol funerario y psicopompo muy destacado que nos ha dejado un gran rastro que procederemos a analizar a continuación.

\section{LA DIVINIDAD CELESTE/SOLAR Y SU CARÁCTER PSICOPOMPO: EL CAZADOR NEGRO}

El sol ha estado tradicionalmente vinculado a las ideas de ultratumba. Su diaria muerte y resurrección le han hecho el máximo exponente de la concepción cíclica del tiempo y de la vida. La orientación al Este de los dólmenes del área soriana, como por ejemplo el excavado en Carrascosa (Soria) ${ }^{89}$, nos hablan de una antiquísima vinculación del sol al destino humano tras la muerte dentro del marco de lo que posteriormente se habría de convertir en la celtiberia. Estos enterramientos orientados al Este, indican la intención de solarizar la suerte del alma con la del curso del sol, lo cual implica la creencia en un «renacimiento», una existencia ulterior en el otro mundo ${ }^{90}$. Este rol funerario de la divinidad solar es posiblemente uno de los más antiguos y por tanto el que gozará de mayor inercia, disfru-

${ }^{86}$ ARBOGAST, R. M. et al:: Archéologie du cheval: Des origenes à la période moderne en France. París, 2002, págs. 70 ss.

87 BLÁZQUEZ, J. M. ${ }^{a}$ : op. cit., pág. 354.

${ }^{88}$ BLÁZQUEZ, J. M. a: «El simbolismo funerario del huevo y la granada», en Imagen y Mito. Madrid, 1977, pág. 83.

${ }^{89}$ JIMENO, A. y FERNÁNDEZ MORENO, J. J.: «El dolmen de El Alto de la Tejera (Carrascosa de la Sierra, Soria). El fenómeno megalítico en el Alto Duero». Trabajos de Prehistoria 49, 1992, pág. 159.

90 ELIADE, M.: Historia de las Creencias y de las Ideas Religiosas. Vol. I: De la prehistoria a los misterios de Eleusis. Madrid, pág. 27. 
tando de cierto predicamento en muchas tradiciones populares, en su papel psicopompo conductor de almas, e incluso propiciador de la resurrección de los muertos $^{91}$.

Mientras que la imagen del caballo es abundantísima en las fíbulas, por su amplia función como talismán, lo cierto es que la imagen del caballo con jinete incluido, donde más veces aparece representada es en las estelas funerarias, especialmente en las de tipo discoidal. Estas estelas discoidales, ampliamente difundidas por todo el mundo mediterráneo y europeo, poseyeron un simbolismo solar indiscutible, con una gran continuidad en su simbolismo a través del tiempo y del espacio ${ }^{92}$. Desde la primera asociación de la imagen del jinete a una estela funeraria de la necrópolis de Aguilar de Anguita (Guadalajara), parece que su simbolismo poco varió a lo largo de los siglos. Es difícil fechar la representación de la estela de Aguilar de Anguita, pues parece que pudo incluso haber sido tomada de algún monumento megalítico, dadas las similitudes de la representación del caballo con el que aparece en el dolmen de Cubillejo de Lara ${ }^{93}$, pero es posible que el enterramiento sea contemporáneo a las primeras representaciones de la divinidad jinete, por tanto en torno al siglo IV a.C. Pero dentro del periodo prerromano, el grupo de estelas más significativo no lo hallamos en la celtiberia sino en las llamadas «estelas gigantes» de Cantabria, grupo que podría fecharse entre los siglos II y I a.C. ${ }^{94}$ No será, no obstante, hasta la conquista romana cuando este tipo de representaciones funerarias alcancen su esplendor. La romanización tuvo resultados espectaculares en la expresión de elementos pertenecientes a lo imaginario indígena, posibilitando la manifestación de una rica iconografía funeraria ${ }^{95}$, datándose los primeros ejemplos en torno al último tercio del siglo $I^{96}$ y teniendo por época de mayor esplendor de las estelas discoideas entre los siglos II y III d.C. ${ }^{97}$.

Julio Caro Baroja ya señaló con respecto a algunas de estas estelas, que los jinetes pudiesen estar representando una divinidad ecuestre ${ }^{98}$, teoría que parece que no acabó de cuajar en su momento y que ahora recuperamos a la vista de todo lo señalado. Posíblemente, de todas las estelas discoideas, la que mayor cantidad de comentarios ha suscitado sea la estela gigante de Zurita en la que aparece en la parte inferir un guerrero devorado por un ave, y en un nivel superior un

91 GÓMEZ-TABANERA, J. M.: «Mito y simbolismo en las estelas funerarias», en Frankovski, E.: Estelas Discoideas de la Península lbérica. Madrid, 1989, pág. 272.

${ }_{92}$ AUSSIBAL, R.: «De la stele discoide romaine aux formes modernes et actualles», en De de la Casa, C. (Coord.): V Congreso Internacional de Estelas Funerarias, Vol. II. Soria, 1993, pág. 631.

${ }_{93}$ ARGENTE, J. L. y GARCÍA-SOTO, E.: «La estela funeraria en el mundo preclásico en la Península Ibérica», en De la Casa, C. (Coord.): 1993 op. cit., pág. 88.

94 MARCO, F.: Las Estelas Decoradas de los Conventos Cesaraugustano y Cluniense. Caesaraugusta 43-44. Zaragoza, 1978, pág. 90.

${ }_{95}$ ABÁSOLO, J. A. y MARCO, F.: «Tipología e iconografía en las estelas de la mitad septentrional de la Península Ibérica», en BELTRÁN, F. (ed.): Roma y el nacimiento de la cultura epigráfica en occidente. Zaragoza, 1995, pág. 333.

96 ABÁSOLO, J. A.: «Las estelas decoradas de la región de Lara de los Infantes. Estudio iconográfico». BSAA 43, 1977, pág. 90.

97 MARCO, F.: 1978, op. cit.

98 CARO BAROJA, J.: Los Pueblos de España: Ensayo de Etnología. Barcelona, 1946, págs. 179 ss. 
jinete a caballo frente a dos guerreros armados con lanza y escudo. Esta estela ha sido abundantemente puesta en relación con las noticias de Silo Itálico (Pun. 341343) y Eliano (De nat. an. X, 22) del ritual de exposición de cadáveres por parte de celtíberos y vacceos ${ }^{99}$. Esta estela nos hablaría de un primer destino tras la muerte, reservado a los guerreros caídos en batalla, quizá similar al Walhalla germano ${ }^{100}$, al que sería conducida el alma del difunto tras ser devorado por las aves, encargadas de transportarlo a lo alto, a un más allá astral ${ }^{101}$.

Sin embargo, el ritual funerario destinado para la mayoría de las personas, poco tenía que ver con el ritual de descarnación propio de los guerreros, pues se trataba de la incineración con posterior inhumación de las cenizas. Pero sin embargo éste está aún más estrechamente ligado a la divinidad solar que el anterior. Para entenderlo mejor deberemos primero aproximarnos a la versión más lúgubre del dios sol, la que le hace soberano del mundo subterráneo de los muertos durante la noche.

Si revisamos lo dicho hasta ahora acerca de las representaciones de la divinidad solar/celeste, vemos que lo más frecuente es que se le represente como un jinete, muy a menudo acompañado de uno o dos perros, mostrándose como un dios cazador. También la divinidad gala Sucellos, dios que porta un mazo y posee carácter infernal, suele aparecer acompañado de un perro en los relieves ${ }^{102}$. Otra divinidad famosa por poseer el mazo es el Dagda irlandés quien con una cara del mazo podía quitar la vida a los hombres y con la otra devolverla, apareciendo como un auténtico señor de la vida y de la muerte ${ }^{103}$. Al igual que los anteriores, el dios cazador es señor de la vida y de los vivos, pero también poseía la facultad de quitar la vida que otorgaba. La estética del jinete cazador no es en absoluto exclusiva de los celtas peninsulares. En el romance de Pwyll, príncipe de Narberth, aparece la figura de Arawn, un cazador a lomos de un caballo pálido que persigue un ciervo con una jauría de perros blancos con las orejas rojas ${ }^{104}$. Esos extraños perros eran los Cwn Annwn o «los sabuesos del Annwn», una especie de perros fantasmales que por la noche perseguían a los muertos, enviados por su amo para encontrar los cadáveres y las almas de los hombres ${ }^{105}$. Estos sabuesos del infierno eran muy conocidos en el folklore de toda Gran Bretaña ${ }^{106}$, así como su siniestro amo, que era el rey del Annwn, el otro mundo ${ }^{107}$, y contrasta con la figura del jinete en su rol beneficioso de cazador divino bajo la forma de Mabon.

El dios jinete en su advocación funeraria se nos presenta pues como un oscuro cazador que en compañía de sus perros busca y da caza durante la noche a las al-

99 MARCO, F.: 1978, op. cit., pág. 38.

100 PERALTA, E.: «Estelas discoideas de Cantabria», en FRANKOVSKI, E.: Estelas Discoideas de la Península Ibérica. Madrid, 1989, pág. 438.

101 SOPEÑA, G.: 1987, op. cit., págs. 77-78.

102 LÓPEZ MONTEAGUDO, G.: 1994, op. cit., págs. 469-470.

103 SJODESTEDT, M. L.: op. cit., págs. 39-40.

104 GREEN, M. J.: 1992, op. cit., pág. 33.

105 GREEN, M. J.: op. cit., pág. 30

106 GRAVES, R.: La Diosa Blanca. Buenos Aires, 1970, pág. 58.

107 GREEN, M. J.: op. cit., pág. 33. 
mas de los muertos. Esta tenebrosa figura también se ha conservado en dos leyendas del folklore peninsular conservadas en la zona del pirineo.

De la primera leyenda se hizo ya eco J. Caro Baroja, se trata del Abade chacurra «los perros del abad». En esta leyenda se narra la historia de un abad, que dejando a medio dar el santo sacramento por salir a cazar con sus perros, es condenado por Dios a vagar eternamente tras sus perros, a los cuales se les oye ladrar las noches de temporal. La figura del abad cazador en algunos lugares recibe el nombre de Eiztari-beltza «el cazador negro»108.

La segunda leyenda, quizás la más famosa, se halla en el pirineo catalán. Se trata de la leyenda del Conde Arnau, a cuya jauría de perros se puede escuchar las noches de luna llena cuando sale de caza este personaje casi diabólico al que también se conoce como «el cazador herrante»109.

J. Caro Baroja ya señaló la similitud de ambos relatos con otros que circulaban por Francia y Alemania que tenían como protagonista al Helljäger «el cazador infernal», también conocida la leyenda como «la caza salvaje» ${ }^{110}$, y que no sería sino la pervivencia del mito de Odín o Wôdan, que marchaba seguido por un cortejo de almas perdidas, encontrándose ramificaciones del mito en todos los pueblos de habla indoeuropea ${ }^{111}$. L. Díaz Viana ${ }^{112}$ recoge un mito burgalés según el cual, la noche de todos los santos, se podría ver en las proximidades del monasterio de Fresdeval la figura de un jinete sobre un corcel blanco que no sería otro que el mismísimo Cid, en una nueva variante del mito del cazador negro. También en Irlanda se haya la narración del jinete que puede ser visto solo en determinadas fechas. Se trata de la leyenda de El encantamiento de Gearoidh larla, en la que aparece un conde brujo capaz de adoptar formas animales y que una vez cada siete años cabalga por el condado de Curragh sobre un corcel de pezuñas de plata. También se dice de este conde, que algún día regresaría al mundo de los vivos y combatiría junto a sus guerreros espectrales contra los ingleses para reinar sobre Irlanda durante cuarenta años $^{113}$. Por último, es posible que este mito sea el que se halle en la base del mito galaico de La Santa Compaña, encontrándose este más alterado que los anteriores pero similar en la forma del cortejo nocturno de espíritus.

El del cazador negro es un mito que ha llegado hasta nuestros días y que podemos encontrar representado en el arte celtibérico, en unas fíbulas de jinete y caballito que portan en su parte delantera una cabeza humana, catalogadas como el grupo $\mathrm{F}$ por M. Almagro-Gorbea y M. Torres ${ }^{114}$. El tema de la cabeza figura en la totalidad del conjunto de las prácticas cultuales célticas con la máxima extensión

108 CARO BAROJA, J.: Algunos Mitos Españoles. Ensayos de Mitología Popular, Madrid, 1941, págs. $71 \mathrm{ss}$.

109 CARO BAROJA, J.: op. cit.

110 ELLIS DAVIDSON, H. R.: op. cit., pág. 148.

111 ELLIS DAVIDSON, H. R.: op. cit., pág. 77.

112 DÍAZ VIANA, L.: op. cit., págs. 104-107.

113 YEATS, W. B.: Leyendas y Folklore Irlandés. Vol. II: El Gato Demoniaco y Otros Cuentos Fantásticos Irlandeses. Palma de Mayorca, 1998, págs. 143-145.

114 ALMAGRO-GORBEA, M. y TORRES, M.: op. cit., pág. 23. 
temporal y geográfica ${ }^{115}$. El hecho de que en el arte celta la cabeza aparezca tan abundantemente representada sobre todo tipo de soportes, induce a pensar que pudo tener funciones talismánicas ${ }^{116}$ que concordarían con la propia función de las fíbulas de caballito. No obstante, el motivo de la cabeza ha sido tradicionalmente puesto en relación con rituales decapitatorios dentro del mundo celtibérico, tomando como base para tal afirmación precisamente las fíbulas que estamos tratando. Hay que señalar que la cabeza poseía un profundísimo simbolismo y valor, más allá de mero trofeo de guerra, de hecho, parece que los celtas consideraron la cabeza como el recipiente del alma, creencia muy difundida en todo el mundo indoeuropeo ${ }^{117}$, y parece que ello hizo que el propio alma humana fuese representada en forma de cabeza. Esto se puede ver muy claramente en una cerámica hallada en Uxama (Burgo de Osma, Soria) en la que se representan unas aves psicopompas transportando almas dentro de una especie de cajitas con alas y que son representadas ni más ni menos que como cabezas. Las cabezas representadas en las fíbulas, lejos de ser por tanto «cabezas trofeo», son la representación de las almas transportadas por dios jinete al más allá, en lo que debió ser una especie de cacería de las mismas, tal y como nos muestran las leyendas. El cazador negro sería conducido por sus perros hacia los moribundos y este les quitaría la vida cazando su alma y transportándola al inframundo.

No cabe duda de que debieron de existir diversos destinos tras la muerte, según se hubiese producido ésta, del sexo, edad o estatus social del difunto. Los que tenían el privilegio de morir en la guerra eran expuestos a ser devorados por buitres y cuervos, quienes se encargarían llevar el espíritu del difunto, tal y como se ve reflejado en el vaso de Uxama, ante la presencia de la divinidad en un más allá celeste, como reflejaría también la estela de Zurita. Relacionado con este ritual de exposición se halla una estela hallada en Alcañiz (Teruel) (Fig. 3), que presenta a un guerrero muerto en combate devorado por unos buitres en presencia de la divinidad jinete que aparece acompañada, como no, de su perro que aparece en la parte inferior. La mano posiblemente diestra que aparece en la parte superior derecha, ha sido puesta en relación con la práctica de la amputación de la diestra, práctica bien documentada en la Península Ibérica ${ }^{118}$, pero es posible que su representación se deba a que se acreditase su posesión, pues fuese éste, requisito indispensable para poder recibir el ritual descarnatorio. Todo parece indicar que la mano derecha sería el símbolo del honor del hombre, y su amputación se realizase como castigo solo a aquellos que faltasen a ese honor, faltando a su palabra o incumpliendo pactos. Este debió ser el caso de los cuatrocientos jóvenes de Lutia castigados de este modo por Escipión por querer ayudar al caudillo numantino Retógenes (Apiano, Iber. 93), pues es posible que el general romano hubiese dispuesto con los lutios algún tipo de pacto con anterioridad por el que se comprometiesen a mantenerse al margen de la contienda. Es posible que la estela en

115 ALBERRO, M.: «El paradigma céltico de las cabezas cortadas y su conexión con la diosa de la guerra», Kalathos 22-23, 2003-04, pág. 196.

116 GREEN, M. J.: 2007, op. cit., pág. 142.

117 ONIANS, R. B.: The Origins of European Thought. Cambridge, 1994, págs. 100 ss.

118 MARCO, F.: «Nuevas estelas ibéricas de Alcañiz (Teruel)». Pyrenae 12, 1976, pág. 87. 


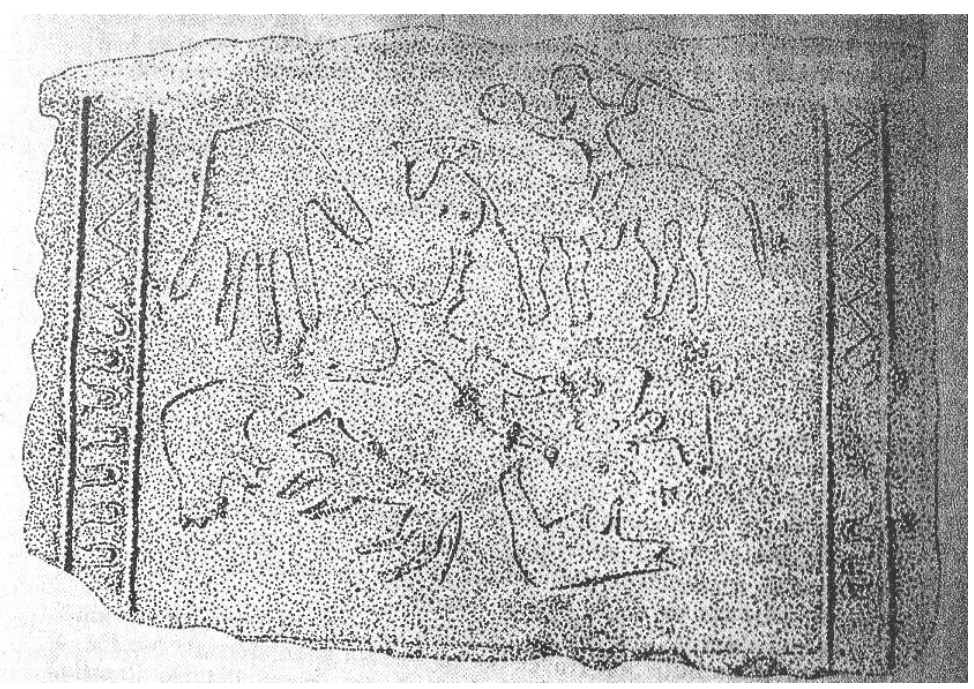

Fig. 3.

cuestión se hallase formando parte de algún tipo de recinto destinado precisamente a la celebración del mencionado ritual descarnatorio.

Todo parece indicar que quienes no eran bendecidos con el honor de morir en combate eran incinerados y sus cenizas depositadas en una urna enterrada como la semilla que es plantada esperando nueva vida. El alma sería captada por la divinidad solar y transportada a un más allá subterráneo, pues la puesta de sol no es sino una bajada del astro a las regiones inferiores y lo atravesaría guiando a las almas de los difuntos ${ }^{119}$. Una representación de las características de ese viaje nocturno lo hallamos en la diadema de Mones (San Martín de Oscos, Asturias) (Fig. 4). Hallamos en la representación de esta diadema una escena de apoteosis guerrera a través de un tránsito acuático al más allá ${ }^{120}$. Se representan tres figuras humanas, la primera de ellas la del jinete solar a lomos de su caballo, en ocasiones seguido de un guerrero a pie que posiblemente represente al difunto, y acompañado también de una figura que porta dos calderos, claramente relacionable con el dios que resucita a los guerreros en el caldero de Gundestrup, y que posiblemente será la encargada de devolver a la vida al guerrero difunto. En la literatura irlandesa, este dios del caldero podría ser identificable con el dios médico Diancecht, que cura a través de su magia actuando sobre el agua para que esta devuelva la salud a los guerreros heridos en combate ${ }^{121}$. Por último, delante de todos ellos aparece una figura animal que ya Marco Simón interpretó como la figura de un perro ${ }^{122}$, sin duda el mismo que acompaña al jinete en iconografía y leyendas. Esta creen-

119 ELIADE, M.: 1981 op. cit., pág. 153.

120 MARCO, F.: «Heroización y tránsito acuático: sobre las diademas de Mones (Piloña, Asturias)», en MANGAS, J. y ALVAR, J. (eds.): Homenaje a J. M. Blázquez, Vol. II. Madrid, 1994, pág. 329.

121 ELLIS DAVIDSON, H. R.: «Las llamadas divinidades de las aguas», en BERMEJO, J. C. (coord.): Mitología y Mitos de la Hispania Prerromana. Madrid, 1986, págs. 175-176. 


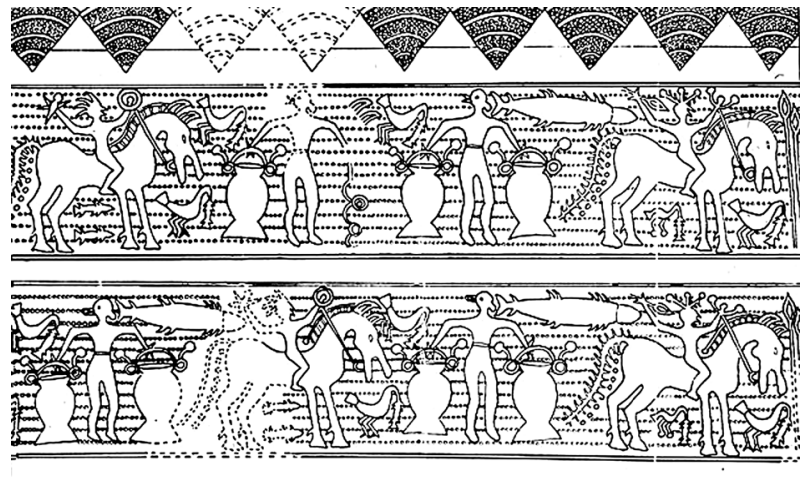

Fig. 4.

cia debió extenderse por un área muy amplia de la Península lbérica, pues la misma idea o similar parece haber estado reflejada en el relieve de las Peñuelas (Martos, Jaén) en el que aparece un caballo con un pez sobre él y una crátera delante, pudiendo tener un significado funerario ${ }^{123}$.

Finalmente, este trabajo no quedaría completo si no tratásemos de hacer un acercamiento a cual pudo ser el nombre que recibiese la divinidad celeste entre los pueblos prerromanos, a través del análisis de las fuentes escritas y los restos epigráficos.

La figura del héroe Mabon de la literatura galesa, es quizá uno de los mejores ejemplos a la hora de comparar a la divinidad solar celtibérica. Parece ser que este héroe es el mismo dios Maponos que aparece en epígrafes del norte de Gran Bretaña y el centro de la Galia ${ }^{124}$. Maponus «joven divino», aparece habitualmente como epíteto de Apolo salvo en dos excepciones ${ }^{125}$ señalando su carácter solar, lo que nos lleva a compararle con otras posibles divinidades solares de la Península Ibérica.

Quizá el caso más claro de una divinidad con las características del dios jinete solar, que aparezca mencionado en las fuentes, sea el del dios Neton. La faceta solar y guerrera de este dios nos es conocida gracias a un pasaje de Macrobio (Sat. I, 19, 5) que nos habla a cerca de su culto entre los accitanos: «Marte solem esse quis dubitat? Accitani etiam hispana gens simulacrum Martis radiis ornatum maxima religione celebrant Neton vocantes». El nombre de esta divinidad aparece muy diseminado por el conjunto de la Península, pudiendo encontrarse en un ara aparecida en Condeixa-a-Velha (CIL II 365) y en otra de Trujillo (CIL II 5278), ambas hoy desaparecidas ${ }^{126}$, pero también en la cara $A$ del Bronce de Botorrita,

122 ELLIS DAVIDSON, H. R.: op. cit., pág. 335.

123 RECIO, A.: «Relieve ibérico funerario con caballo de Las Peñuelas (Martos)», en MANGAS, J. y ALVAR, J. (eds.): Homenaje a José Ma. Blázquez, Vol. II. Madrid, passim.

124 GREEN, M. J.: 1992 op. cit., pág. 137.

125 GREEN, M. J.: op. cit., pág. 140; LÓPEZ MONTEAGUDO, G.: op. cit., págs. 476-477.

126 OLIVARES PEDREÑO, J. C.: Los Dioses de la Hispania Céltica. Madrid, 2002, pág. 39. 
mencionado como Neito, probablemente también el mismo dios Neitin que pudiera mencionarse en el Monumento de Binéfar (Huesca) ${ }^{127}$. La iconografía que muestra esta pieza, donde predomina lo bélico y la representación de manos cortadas $^{128}$ nos confirmaría ese carácter guerrero del Neton de Macrobio. Pero esas manos cortadas también nos recuerdan a la que se representa en la estela de Alcañiz, mostrándonos además de la faceta guerrera, la de protector y garante de los pactos, hipótesis ya señalada también por F. Marco y V. Valdellou ${ }^{129}$. Neton se muestra pues como uno de los múltiples nombres que pudo recibir la divinidad solar, sobre todo al parecer dentro de su función guerrera.

Dado el carácter plurifuncional que presenta la divinidad jinete solar, otra divinidad con la que parece concordar enormemente es Lugus. En la literatura irlandesa, el dios Lug «el resplandeciente» está claramente asociado con la luz brillante pudiendo haber sido un dios del sol, se nos presenta como un joven guerrero divino vencedor del mal ${ }^{130}$. Una posible explicación del nombre de la divinidad vendría desde el radical leuk- «brillar» ${ }^{131}$, haciendo referencia a la faceta solar del dios, que también es apoyada por uno de sus epítetos más comunes en la literatura irlandesa Grianainech «cara de sol»" ${ }^{132}$. Pero también parece posible que Lugus signifique «dios de los pactos», indicándonos una de sus principales funciones ${ }^{133}$, la de protector de los pactos y juramentos que como ya vimos, poseería la divinidad. También se ha señalado la posibilidad de que el nombre de este dios provenga del vocablo galo Lugos "cuervo» apoyado en la relación existente entre el dios y estos animales ${ }^{134}$. Este significado de Lug resulta interesante pues en la inscripción de Peñalba de Villastar (Teruel) en la que se cita dos veces al dios, haya pintado debajo de ella según Cabré un cuervo, relacionándose de este modo también con Apolo, divinidad de la luz frecuentemente asociada con los cuervos, y con Mithra, divinidad del mismo carácter a la que también suele acompañar dicho animal ${ }^{135}$. También el dios germano Odín era visto como un personaje oscuro al que acompañaban dos cuervos, Hugin y Munin, y de hecho se le solía llamar Hrafnagud «dios de los cuervos» (Gylfaginning XXXVIII, 106).

El carácter plurifuncional que hemos visto posee la divinidad celeste/solar, concuerda sobre manera con otro de los epítetos del dios Lug, Samh-íl-dánach «el politécnico», el «hábil en muchas artes» ${ }^{136}$ tal y como se presenta a sí mismo en la corte del rey Nuadu en Tara. También poseía el epíteto Lámfhada «el del largo brazo», probablemente en referencia a su modo de hacer la guerra, siempre atacando desde la distancia con sus armas arrojadizas ${ }^{137}$, su lanza maravillosa Gai Bolga

127 MARCO, F. y VALDELLOU, V.: «El monumento ibérico de Binéfar». Pyrenae 12, 1976, pág. 108109.

128 MARCO, F. y VALDELLOU, V.: op. cit., págs. 109 ss.

129 MARCO, F. y VALDELLOU, V.: op. cit.

130 GREEN, M. J.: 1995 op. cit., pág. 48.

SOPEÑA, G.: 1987 op. cit., pág. 38.

32 OLMSTED, G.: op. cit., págs 116-117.

OLMSTED, G.: op. cit.

GREEN, M. J.: op. cit.

BLÁZQUEZ, J. M. a: 1962 op. cit., pág. 89.

136 SOPEÑA, G.: op. cit., págs. 38-39. 
y su honda, con la que da muerte al gigante Balor (mito posiblemente reflejado en la estela cluniense anteriormente señalada y que tendría a la divinidad jinete como protagonista). En relación con este epíteto poseemos dos epígrafes a los dioses Lugubo Arquienobo y Lucoubus Arquienis aparecidas en Sober (Lugo) y Otero del Rey (Lugo) respectivamente. Ambas son dedicaciones a Lugu en plural, y el epíteto se basa en la raíz indoeuropea $\operatorname{Arkw}(u)$ - «arco, curvatura», forma eminentemente itálica y germánica documentada en el latín arcus, gót. Arhwana «flecha» ${ }^{138}$, con el que se haría referencia a esa característica del dios de atacar a distancia, en este caso con arco y flechas, lo que podría señalar una avanzada fase de identificación del dios Lugus con Apolo y sus atributos. También existen dedicatorias al dios Lugus en el área de la Meseta. El ejemplo más famoso es una dedicatoria a Lugovibus Sacrum (CIL II 2818), procedente de las ruinas de la antigua Uxama (Burgo de Osma, Soria), dedicada por un L. Licinius del colegio de zapateros de la ciudad (collegio sutorum) y que fue reutilizada como pila de agua bendita en la ermita de San Roque de la misma localidad ${ }^{139}$.

Lug es posiblemente la divinidad que mayor cantidad de topónimos posee en toda la Europa Céltica. En la Península Ibérica, Ptolomeo (II, 6, 32) señala la existencia de un pueblo de los Lougonoi, documentado como los Luggoni por otras fuentes y que se relaciona con los Lougoi de Escocia del mismo autor (II, 3, $8)^{140}$. Encontramos también topónimos como Lucus Augusti (Lugo), Lucus (Lugo de Llanera, Asturias), la civitas Lougeiorum, Louciocelum, Lucocadia, Lugones (Siero, Asturias) derivado probablemente de los antiguos Luggoni, Logobre, Santa María de Lugo y Lugás ${ }^{141}$. También en las cercanías del santuario de Peñalba de Villastar encontramos topónimos relacionados con la divinidad en las actuales localidades de Luco de Bordón y Luco de Jiloca ${ }^{142}$.

La inscripción del santuario rupestre de Peñalba de Villastar (Teruel) está fechada en torno a mediados del siglo I d.C. y supone la inscripción religiosa más larga dedicada a Lugus que se conoce en toda Europa. Según W. Meid ${ }^{143}$, en la inscripción se habla de un pueblo que va al santuario en procesión a través de los campos, y que construyen un togias «estructura techada» en conmemoración y para el disfrute del dios y su devotos (thiasus). Aparecerían en la inscripción dos epítetos referentes al dios, eniorosei y equeisui. El primero de los epítetos estaría formado por eni-oros-ei «el que mora en la montaña», equiparando al dios con las divinidades celestes que habitan en las montañas, un «montanus». El segundo epíteto, equeisui, califica al dios como «eques», mostrando una asociación del dios con cumbres de montañas y caballos que es también característica del Lug de la

137 SJOESTEDT, M. L.: op. cit., pág. 43.

138 PRÓSPER, B. M. ${ }^{\text {a: }}$ Lenguas y Religiones Prerromanas del Occidente de la Península lbérica. Salamanca, 2002, pág. 311.

139 OLIVARES PEDREÑO, J. C.: op. cit., pág. 113.

140 MARCO, F.: «El dios céltico Lug y el santuario de Peñalba de Villastar», en Estudios en Homenaje al Dr. Antonio Beltrán Martínez. Zaragoza, 1986, págs. 732-733.

141 OLIVARES PEDREÑO, J. C.: op. cit., pág. 203.

142 MARCO, F.: op. cit., pag. 742.

143 MEID, W.: Celtiberian Inscriptions. Budapest, 1994. 
tradición céltica insular ${ }^{144}$. Señala Meid que ese equeisui podría referirse a un epíteto del dios en su forma de caballo semental y a una hierogamia del dios con la diosa céltica de los caballos, la yegua divina ekwona ${ }^{145}$. El mismo epíteto también podría estar en relación con el epíteto eochaid «el jinete» con que suele ser calificado el dios irlandés Dagda, con quien nuestro dios jinete guarda muchas similitudes. Otro epíteto relacionado sería el Equeunu(bo), mencionado en un ara encontrada en la ermita de San Lorenzo, en La Vid (Pola de Gordón, León) analizada por $\mathrm{F}$. Marco ${ }^{146}$ y que también le llevó a relacionarlo con el equeisui de la inscripción de Peñalba. Estos epítetos nos remarcan la relación del dios Lugus con los caballos y no en vano, según las leyendas irlandesas, Lug fue el primero en montar a caballo y por ello en el festival de Lugnasad se celebraban carreras de caballos en su honor ${ }^{147}$. Esta imagen de Lug como jinete divino llevó ya a E. Peralta a identificar en algunos casos al jinete de las estelas funerarias con este dios ${ }^{148}$.

Otros nombres de divinidades como Eaecus, que aparece frecuentemente asimilado a Júpiter bajo la forma lupiter Solutorius Eaecus, pero también a Apolo, que incluso pudo tener un colegio sacerdotal en Poza de la Sal (Burgos) $)^{149}$, o la divinidad Reve, también dios del cielo con culto en los montes, relacionada con los ríos y que en ocasiones comparte epítetos con Júpiter ${ }^{150}$, pudieron hacer referencia a esa misma divinidad solar/celeste que hemos estado tratando. Pero sin lugar a dudas, de entre todos los posibles nombres, el de Lug o Lugus, parece ser el que más abundantemente se relaciona con el dios jinete y mejor encaja en sus funciones.

Sin duda, un análisis acerca de la interpretatio romana nos ayudaría a comprender mejor las características y evolución de la divinidad celeste/solar del panteón indoeuropeo peninsular. No obstante, tal empresa nos obligaría a extendernos en demasía, superando las expectativas creadas para este trabajo, que solo pretende ser una introducción al estudio de las divinidades prerromanas peninsulares, por lo que dejamos pendiente tal labor para un próximo trabajo.

El dios jinete solar adorado por los celtíberos se nos presenta pues como una divinidad con amplias competencias que le hicieron valedero de numerosos epítetos además de los distintos nombres que pudiera recibir en cada rincón de la geografía hispana. Su popularidad se vio reflejada en la enorme cantidad de representaciones que nos han llegado de él, y que nos hablan de unas gentes sumamente religiosas que tomaron el arte como vehículo de expresión de sus creencias. En este aspecto las fíbulas de caballito y sus variantes no debieron ser

144 MEID, W.: «The interpretation of celtiberian inscriptions», en VILLAR, F. y BELTRÁN, F. (eds.): Pueblos, Lenguas y Escrituras en la Hispania Prerromana. Salamanca, 1999, págs. 493-494.

145 MEID, W.: 1994 op. cit., pág. 35.

146 MARCO, F.: ««DEVS EQVEVNV(BO)»», en VILLAR, F. y BELTRÁN, F. (eds.): Pueblos, Lenguas y Escrituras en la Hispania Prerromana. Salamanca, 1999, passim.

147 MEID, W.: 1994 op. cit., pág. 37; OLMSTED, G.: op. cit., pág. 117.

148 PERALTA, E.: op. cit., pág. 446.

149 FERNÁNDEZ FÚSTER, L.: «Eaecus». Aportación al estudio de las religiones primitivas hispánicas». AEA 28, 1955, passim.

150 OLIVARES PEDREÑ̃, J. C.: op. cit., págs. 169 ss. 
objetos exclusivos de una clase social guerrera masculina predominante, pues debieron ser portadas por los devotos como meros adornos religiosos, incluido por supuesto el grupo femenino, tal y como se aprecia en la necrópolis de Numancia, donde estos adornos aparecen en su mayoría vinculados a ajuares femeninos ${ }^{151}$. También los «báculos de distinción» se hallan mayoritariamente vinculados a ajuares con adornos, de hecho 9 de los 13 báculos hallados se encontraron asociados a agujas de coser, «armazón de tocado» y placas decoradas ${ }^{152}$. Buena parte de estos báculos representan la temática del «cazador negro», representándose a éste a caballo con representaciones de las almas, con forma de cabecitas, asociadas a él, por lo que podrían aparecer en las tumbas, por su simbolismo claramente funerario. Pero el hecho de que apareciese uno de estos báculos en contexto doméstico durante unas excavaciones, nos inclina a pensar que pudieron ser empleados en algún ritual religioso, siendo portados por una personalidad religiosa destacada. Es probable que la mujer jugase un papel religioso muy importante y poco conocido en la sociedad celtibérica y que esos báculos pudieran haber sido portados por algún tipo de sacerdotisa en rituales inciertos, pero quizá relacionados con el mundo funerario y la auguración.

A la vista de los datos, podemos afirmar que en efecto sí existió un panteón religioso entre los pueblos prerromanos peninsulares, en cuya cúspide se encontraba un dios jinete vinculado al sol y al cielo. De hecho a través del análisis de su iconografía hemos concluido que era partícipe de numerosos mitos, la mayoría comunes al resto de divinidades celestes del mundo indoeuropeo, con las que compartía sus características. Y además parece que poseyó un culto que lejos de restringirse a una clase social, debió de gozar de enorme popularidad.

Las creencias y mitos que envolvieron a la divinidad celeste, debieron de gozar de una enorme fuerza y popularidad. De hecho, hemos comprobado como todavía a día de hoy perviven en las leyendas y las historias que nos cuentan la mayor de las veces los más ancianos, herederos de un mundo sin televisión en el que las gentes disfrutaban durante las noches, sentándose en torno a una hoguera y contando leyendas e historias transmitidas desde tiempos remotos y hace ya mucho olvidados.

\footnotetext{
151 JIMENO, A.; De la TORRE, J. I.; BERZOSA, R. y MARTíNEZ, J. P.: La Necrópolis Celtibérica de Numancia. Soria, 2004, pág. 188.

152 JIMENO, A.; De la TORRE, J. I.; BERZOSA, R. y MARTÍNEZ, J. P.: op. cit., pág. 163.
} 
|06_RubenAbad.qxp 8/1/10 08:31 Página 104 